\title{
Occurrence of potato yellowing virus in naranjilla (Solanum quitoense Lam.) in Ecuador
}

\author{
Karla Ramos $^{1} \cdot$ Yeturu Sivaprasad $^{2} \cdot$ Fiama Guevara $^{1}$ • Francisco Ochoa-Corona ${ }^{3} \cdot$ William Viera $^{2}$ (D) Francisco Flores $^{1,4}$
}

Received: 20 September 2019 / Accepted: 6 December 2019 /Published online: 18 December 2019

(C) Società Italiana di Patologia Vegetale (S.I.Pa.V.) 2019

Keywords Bromoviridae $\cdot$ Ilavirus $\cdot$ High throughput sequencing $\cdot$ Complete genome $\cdot$ Solanaceae

Naranjilla (Solanum quitoense Lam.) is a fruit native to Ecuador and Colombia. It is consumed mainly as fresh fruit or juice. The cultivated area in Ecuador is $c a .2,342$ ha and the average yield is $6.04 \mathrm{t} \mathrm{ha}^{-1}$ (MAG 2017). Starting in 2015, generalized chlorosis, inter veins-space yellowing or chlorotic areas and young leaf curling symptoms were detected in plants of $S$. quitoense in Tumbaco, Pichincha, in plants of common origin at the INIAP Experimental Farm, Ecuador. The occurrence of potato yellowing virus (PYV) was confirmed in symptomatic leaves, from INIAP experimental farm, by DAS-ELISA with PYV specific antiserum (Sivaprasad et al. 2015), eight out of ten plants tested positive. High throughput sequencing (HTS) was carried out on a pool of RNA from leaves of three different symptomatic plants . Total RNA was isolated using the PureLink RNA mini kit (Invitrogen), libraries were prepared with the TruSeq Stranded Total RNA LT Kit (Illumina) and sequenced with the Illumina NovaSeq platform. A total of 92 million 150-bp reads were obtained. After cleaning, deduplication, and host genome sequence elimination, sequences were assembled with Spades-V3.13. From a total of 134503 contigs, 24 mapped to the PYV ge-

William Viera

william.viera@iniap.gob.ec

1 Departamento de Ciencias de la Vida y la Agricultura, Universidad de las Fuerzas Armadas (ESPE), Sangolquì 170501, Ecuador

2 National Institute of Agricultural Research (INIAP), Fruit Program, Tumbaco, Quito 170184, Ecuador

3 National Institute for Microbial Forensics \& Food and Agricultural Biosecurity, Oklahoma State University, Stillwater, OK 74078, USA

4 Centro de Investigación de Alimentos, Facultad de Ciencias de la Ingeniería e Industrias, Universidad UTE, 170147 Quito, Ecuador nomes with an average coverage of $1500 \mathrm{X}$. These contigs were used to assemble the complete PYV RNA1, RNA2 and nearly complete RNA3 using Geneious-R11. Sequences were deposited in GenBank with accession numbers (MN544549MN544551). Tobacco virus 2, potato leafroll virus, tobacco vein clearing virus, and tomato torrado virus were also found with a lower coverage, therefore the observed symptoms cannot be attributed to PYV only. The RNA dependent RNA polymerase gene (RdRp) was used for a phylogenetic analysis using BEAST under the $\mathrm{LG}+\mathrm{G}$ model and a strict molecular clock. The phylogeny showed that the PYV isolate from naranjilla clustered with an isolate described in pepper from the same location in Tumbaco (KP772263) (Sivaprasad et al. 2015), but was distantly related with isolates from Solanum phureja from other locations in Ecuador (Silvestre et al. 2011) Moreover, the PYV RNAs have 80.1, 78.1 and 73.5 identity with Fragaria chiloensis latent virus, (NC_006566, NC_006567, NC_006568) which confirms that PYV as a distinct Ilavirus (family Bromoviridae). To our knowledge, this is the first report of PYV infecting S. quitoense as a new host.

\section{References}

Ministerio de Agricultura y Ganadería MAG (2017) Boletín Situacional Naranjilla. Sistema de Información Pública Agropecuaria, Quito

Silvestre R, Untiveros M, Cuellar WJ (2011) First report of potato yellowing virus (Genus Ilarvirus) in Solanum phureja from Ecuador. Plant Dis 95:355

Sivaprasad Y, Garrido P, Méndez K, Garrido A, Ramos L (2015) First report of potato yellowing virus infecting pepper in Ecuador. J Plant Pathol 97:75

Publisher's note Springer Nature remains neutral with regard to jurisdictional claims in published maps and institutional affiliations. 